\title{
Solid organ transplantation following allogeneic haematopoietic cell transplantation: experience from a referral organ transplantation center and systematic review of literature
}

\author{
Jens G. Brockmann ${ }^{1} \cdot$ Dieter C. Broering ${ }^{1} \cdot$ Syed M. Raza ${ }^{1}$. Walid Rasheed ${ }^{2} \cdot$ Shahrukh K. Hashmi $^{2}$ • \\ Naeem Chaudhri ${ }^{2} \cdot$ Imran Y. Nizami $^{3} \cdot$ Jehad A. H. Alburaiki ${ }^{4} \cdot$ Mohamed A. Shagrani $^{5} \cdot$ Tariq Ali $^{6} \cdot$ Mahmoud Aljurf $^{2}$
}

Received: 21 April 2018 / Accepted: 20 May 2018 / Published online: 6 August 2018

(c) Macmillan Publishers Limited, part of Springer Nature 2018

\begin{abstract}
Solid organ transplantation (SOT) following haematopoietic cell transplantation (HCT) is a rare event. Uncertainty exists whether such recipients are at higher risk of relapse of underlying haematological disease or at increased risk of developing infectious or immunological complications and malignancies following SOT. The experience at our referral organ transplantation center and the present literature of SOT $(n=198)$ in recipients following previous HCT was systematically reviewed. Outcome analysis of 206 SOT recipients following HCT challenges the validity of the frequently stated comparable outcome with recipients without prior HCT. SOT recipients after HCT are younger and have a higher mortality and morbidity in comparison with "standard" recipients. Rejection rates for SOT recipients following HCT appear to be lower for all organs, except for liver transplantation. In the setting of liver transplantation following HCT, mortality for recipients of deceased donor grafts appears to be exceptionally high, although experience with grafts of living donors are favourable. Morbidity was mostly associated with infectious and malignant complications. Of note some SOT recipients who received solid organ donation from the same HCT donor were able to achieve successful withdrawal of immune suppression. Despite limited follow-up, recipients with prior HCT show a different course after SOT, necessitating attention and closer follow-up.
\end{abstract}

Electronic supplementary material The online version of this article (https://doi.org/10.1038/s41409-018-0255-9) contains supplementary material, which is available to authorised users.

Jens G. Brockmann

brockmannjgb@me.com

1 Department of Surgery, Organ Transplant Center, All King Faisal Specialist Hospital and Research Center, Riyadh, Saudi Arabia

2 Department of Medical Oncology, All King Faisal Specialist Hospital and Research Center, Riyadh, Saudi Arabia

3 Organ Transplant Centre, Lung Transplant Medicine, All King Faisal Specialist Hospital and Research Center, Riyadh, Saudi Arabia

4 Department of Cardiology, All King Faisal Specialist Hospital and Research Center, Riyadh, Saudi Arabia

5 Organ Transplant Center, Department of Paediatric Transplant Hepatology, Organ Transplant Center, All King Faisal Specialist Hospital and Research Center, Riyadh, Saudi Arabia

6 Organ Transplant Center, Department of Kidney and Pancreas Transplant Nephrology, Organ Transplant Center, All King Faisal Specialist Hospital and Research Center, Riyadh, Saudi Arabia

\section{Introduction}

Allogeneic hematopoietic cell transplantation (HCT) is the only cure for numerous malignant and non-malignant diseases of the lympho-hematopoietic system with otherwise fatal prognosis. Morbidity and mortality associated with treatment-related organ toxicity is limiting its success. Organ failure can be secondary to pre-transplant treatment exposures, and organ injury because of conditioning regimen toxicity, graft-versus-host disease (GVHD) and/or infections. Conservative therapeutic strategies are only partially effective resulting in mortality. During recent decades, solid organ transplantation (SOT) has occasionally been used for treatment of terminal organ failure in HCT recipients. SOT included kidney, liver, lung and heart grafts for a variety of HCT-related complications.

Although, SOT following HCT has been performed for more than 25 years, comprehensive information regarding its benefit in terms of overall survival and continuative organ function is limited and only provided by case reports or case series. Limited compilation of reported cases may 
Table 1 Performance and outcome for kidney transplantation following HSCT

\begin{tabular}{|c|c|c|c|c|c|c|c|c|}
\hline Author ${ }^{\text {ref }}$ (year) & $n$ & $\begin{array}{l}\text { Mean age at } \\
\text { SOT in y } \\
\text { (range) }\end{array}$ & $\begin{array}{l}\text { SOT donor } \\
\text { (time from HCT } \\
\text { to SOT) }\end{array}$ & $\begin{array}{l}\text { Follow-up in } \\
\text { m mean } \\
\text { (range) }\end{array}$ & $\begin{array}{l}\% \text { Patient } \\
\text { survival }\end{array}$ & $\begin{array}{l}\% \text { Graft } \\
\text { survival }\end{array}$ & $\begin{array}{l}\text { Rejection in } \\
\%\end{array}$ & Complications/remarks \\
\hline $\begin{array}{l}\text { Sayegh [7] } \\
(1991)\end{array}$ & 2 & $\begin{array}{l}14 \\
30\end{array}$ & $\begin{array}{l}\text { Same as HCT } \\
\text { Same as HCT }\end{array}$ & $\begin{array}{l}12 \\
24\end{array}$ & 100 & 100 & 0 & $\begin{array}{l}1 \text { GVHD } \\
1 \text { Patient off IS }\end{array}$ \\
\hline $\begin{array}{l}\text { Jacobsen [8] } \\
(1994)\end{array}$ & 1 & & Same as HCT & 18 & 100 & 100 & 0 & Off IS at 1 year \\
\hline Helg [9] (1994) & 1 & & Same as HCT & na & 100 & 100 & 0 & Off IS \\
\hline $\begin{array}{l}\text { Sorof [10] } \\
(1995)\end{array}$ & 1 & & Same as HCT & na & 100 & 100 & 0 & Off IS at 1 year \\
\hline $\begin{array}{l}\text { Butcher [11] } \\
\text { (1999) }\end{array}$ & 6 & $34-49$ & $\begin{array}{l}\text { 3/6 Same } \\
\text { 3/6 Different }\end{array}$ & $15(3-30)$ & 83 & $\begin{array}{l}83 \\
2\end{array}$ & 0 & $\begin{array}{l}1 \text { Death due to metatstatic } \\
\text { vaginal SCC }\end{array}$ \\
\hline $\begin{array}{l}\text { Hawami [12] } \\
\text { (2003) }\end{array}$ & 10 & $9-55$ & $\begin{array}{l}\text { 6/10 Same } \\
\text { 4/10 Different }\end{array}$ & $34(2-105)$ & 60 & 60 & 0 & $\begin{array}{l}\text { Interstitial pneumonitis } \\
\text { Pneumococcal sepsis } \\
\text { Aspergillus infection } \\
\text { Myocardial infarction }\end{array}$ \\
\hline $\begin{array}{l}\text { Thomas [13] } \\
\text { (2004) }\end{array}$ & 3 & $8-14$ & All different & $41(7-72)$ & 100 & 100 & 0 & n.a. \\
\hline $\begin{array}{l}\text { Beitinjaneh [14] } \\
(2010)\end{array}$ & 7 & $11-65$ & All different & $44(6-108)$ & 57 & 100 & 0 & $\begin{array}{l}1 \text { Cardiac death at } 9 \text { years } \\
1 \text { Death to tongue cancer }\end{array}$ \\
\hline $\begin{array}{l}\text { Koenecke [1] } \\
(2010)\end{array}$ & $13(15)$ & $3-59$ & $\begin{array}{l}\text { 4/13 Same } \\
\text { 9/13 Different }\end{array}$ & $86(0-280)$ & 100 & 85 & $\begin{array}{l}38 \\
5\end{array}$ & $\begin{array}{l}4 \text { Rejections, } 2 \text { graft losses } \\
\text { due to rejection, } 2 \text { severe } \\
\text { UTIs reported }\end{array}$ \\
\hline $\begin{array}{l}\text { Bunin [37] } \\
(2010)\end{array}$ & 3 & $3-4.5$ & $\begin{array}{l}\text { 1/3 Same }(32) \\
2 / 3 \text { Different } \\
(26,28)\end{array}$ & $30(18-51)$ & 100 & 100 & 0 & \\
\hline $\begin{array}{l}\text { Fangmann [38] } \\
\text { (2011) }\end{array}$ & 1 & 18 & Same & 66 & 100 & 100 & 0 & No IS \\
\hline $\begin{array}{l}\text { Younge [24] } \\
(2015)\end{array}$ & 1 & & Same & 120 & 100 & 100 & 0 & No IS \\
\hline $\begin{array}{l}\text { Schwarz [39] } \\
\text { (2016) }\end{array}$ & 1 & 22 & Same & 12 & 100 & 100 & 0 & Steroid only \\
\hline $\begin{array}{l}\text { KFSH\&RC, } \\
\text { Riyadh }\end{array}$ & 3 & $\begin{array}{l}15 \\
8 \\
33^{*}\end{array}$ & $\begin{array}{l}\text { Different (94 } 65 \\
216)\end{array}$ & $\begin{array}{l}13 \\
15 \\
16\end{array}$ & 100 & 100 & 33 & $\begin{array}{l}\text { Nil } \\
\text { BK Virus nephropathy }\end{array}$ \\
\hline Total & 53 & $18.4(3-65)$ & $\begin{array}{l}22 \text { Same } \\
30 \text { Different }\end{array}$ & $47.4(0-280)$ & 84.6 & 80.8 & 13.5 & \\
\hline
\end{tabular}

*Including one SPK

IS immunosuppression

provoke misinformation, since an undetermined number of unsuccessful cases may not have been reported. Best published evidence for SOT following HCT so far came from the Chronic Leukaemia Working Party of the European Group of Blood and Marrow Transplantation (EBMT) carrying out a questionnaire-based survey within EBMT centres identifying 52 SOTs after allogeneic HCT [1].

This systematic review analyses all reported cases of SOT following HCT with respect to type of transplant (deceased versus living donor), associated complications and mortality. Additionally, our local experience of three lung, two kidney, one simultaneous pancreas and kidney (SPK) and one heart transplantation (HTX) is presented. The objective of this review is to determine whether i. SOT recipients with prior HCT might require different immunosuppression,

ii. SOT recipients post-HCT are at higher risk for infections, rejections or GVHD and

iii. is SOT following HCT justifiable?

\section{Material and methods}

Own data, as well as published reports were systemically reviewed. A comprehensive MEDLINE search was carried out in order to identify published articles on SOT following HSCT. Search terms were 'bone marrow transplant,' 'hematopoietic stem cell transplant,' 'solid organ transplant,' 'renal transplant,' 'kidney transplant', 'liver transplant,' 'lung 


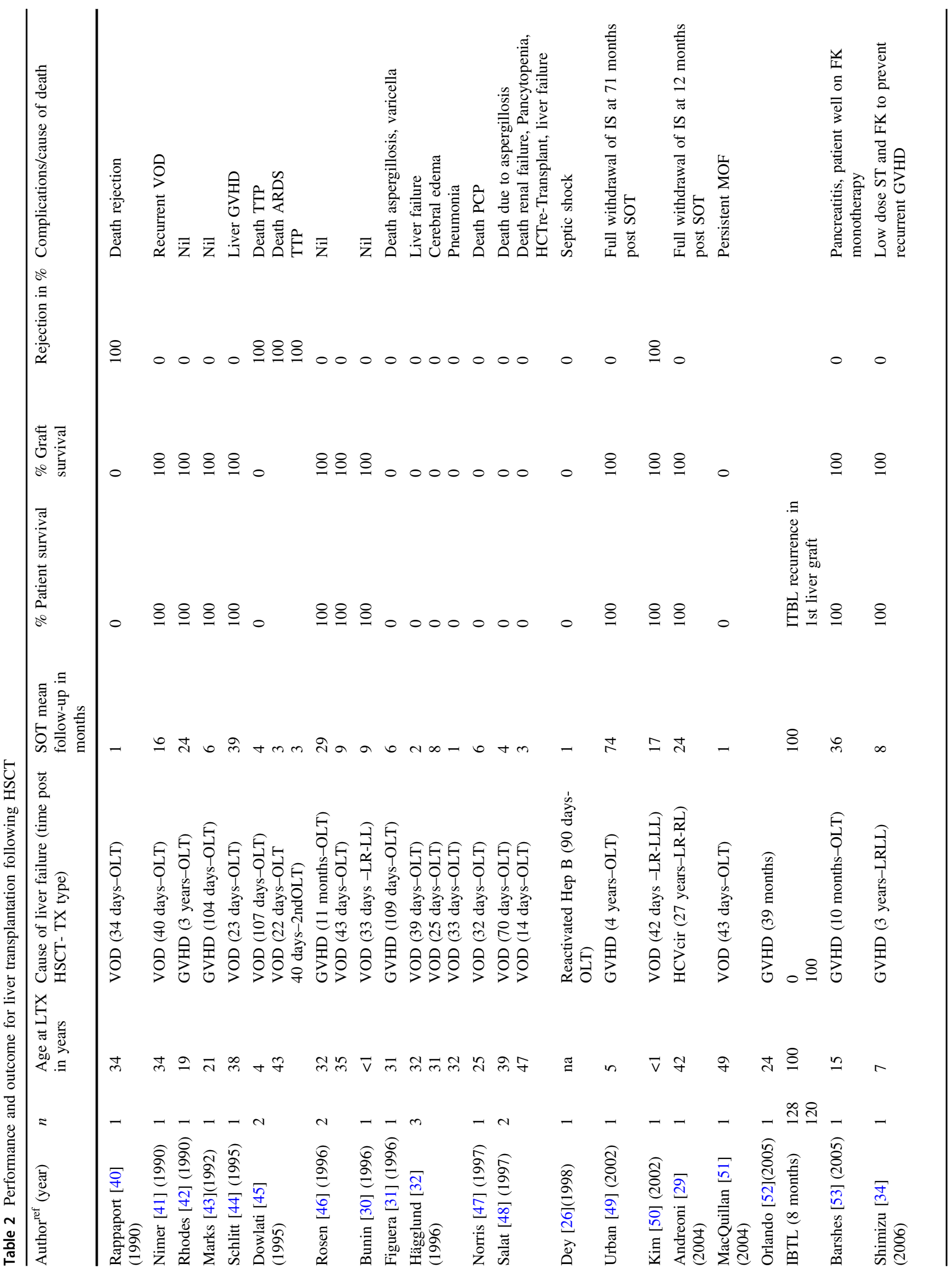




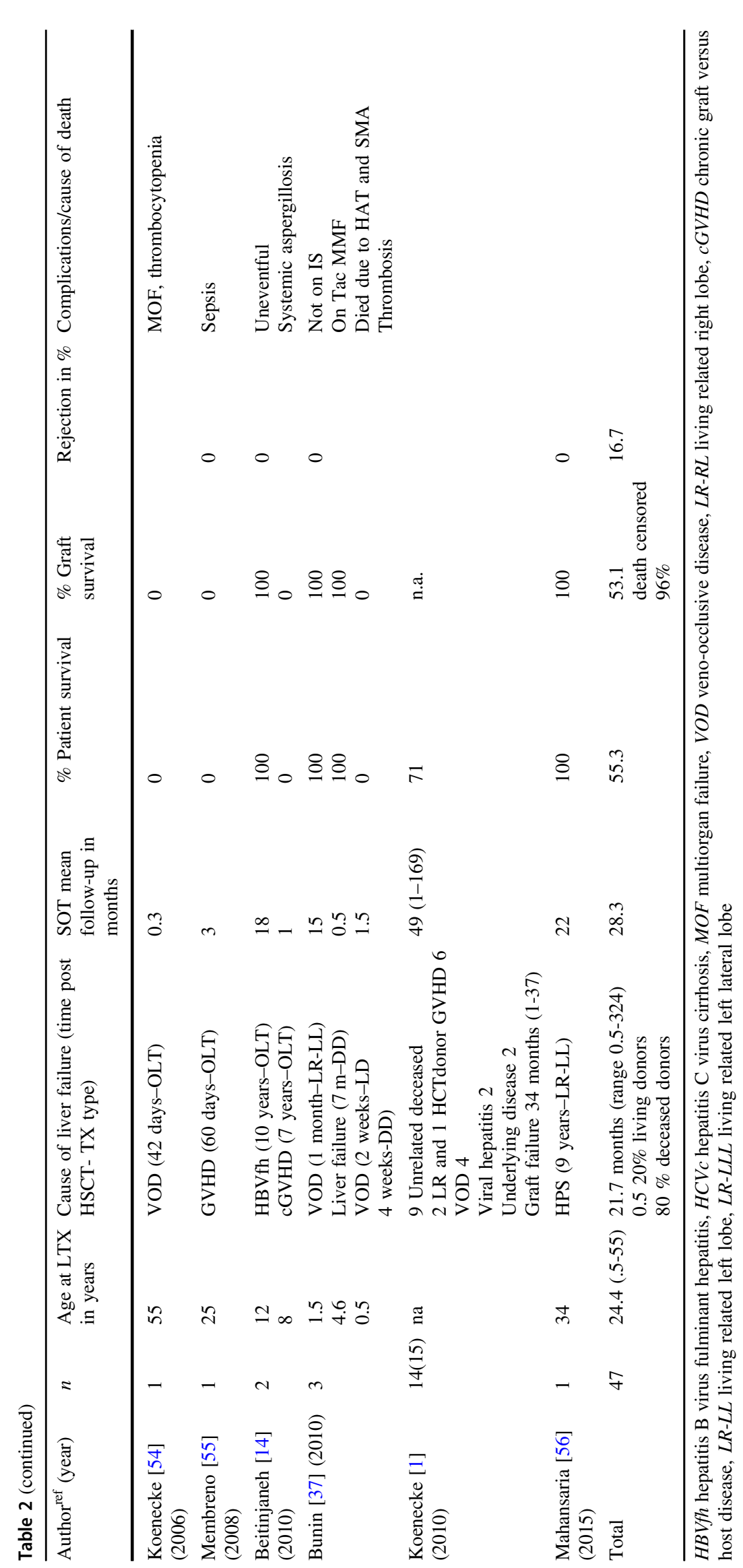


transplant', 'pancreatic transplant', 'heart transplant,' 'intestinal transplant', 'small bowel transplant' and 'cardiac transplant'. The references of all relevant papers were manually reviewed for studies not found via MEDLINE. A total of 253 reports were identified and reviewed for repeat publication, and in case excluded. Only SOT following HCT were considered for analysis, autologous HCT before and HCT after SOT were excluded. Seven HCT recipients receiving eight SOT at King Faisal Specialist Hospital and Research Center (KFSH\&RC) were extensively reviewed and included in the systemic analysis.

Review for outcomes included SOT survival, deathcensored graft survival and patient survival. Definitions for organ failure were death due to impaired organ function, organ replacement, re-transplantation in lung and liver transplant recipients. In renal transplant recipients, graft loss was determined by re-transplantation or return to dialysis. Need for insulin post pancreas transplant and heart failure and need for re-transplantation were considered graft failure in the setting of pancreas and heart SOT post HCT. The cumulative incidences of relapse and SOT graft failure were calculated using competing events statistics. Non-relapse mortality was considered as competing event for relapse incidence. All-cause mortality, except for failure of the transplanted organ was considered as competing event for organ-specific failure rates.

\section{Results}

\section{Kidney transplantation (KTX) after HSCT}

An estimated $18-66 \%$ of allogeneic HCT survivors develop chronic renal insufficiency [2-5]. Renal failure post HCT can be attributed to a number of aetiologies, including radiation, cytotoxic therapy, nephrotoxic agents, chronic GVHD or transplant associated thrombotic microangiopathy. Among patients who progress to end stage renal disease (ESRD) and are in need for haemodialysis, mortality approaches $90 \%$ and renal transplant may be the only therapy that may offer a chance for long-term survival [6]. Although experience in HCT survivors is limited to a total number of 53 kidney transplants (Table 1) published outcomes conclude that it is feasible in selected patients [7-14].

Main reason for ESRD in HCT recipients is drug nephrotoxicity secondary to immunosuppressive or antifungal drug exposure $(n=7)$. One KTX was performed due to long-term toxicity of immunosuppressive medication for a heart transplant following HCT. Other single causes for ESRD are Wiskott-Aldrich syndrome, diabetes mellitus type I and one kidney failure was considered secondary to conditioning radiation therapy. All patients undergoing
KTX after HCT were dialysis dependent. One patient had kidney failure for unknown reason, two required second KTX for rejection. Twenty-two out of 53 kidney recipients received the kidney from their HCT donor. The absence of third party alloreactivity may potentially enable weaning off immunosuppression. This was achieved in a total of six cases (27\%). One additional case was reported to be only on corticosteroid maintenance. On the other hand, subjecting a recipient with a second encounter of identical donor lymphocytes might potentially increase the risk of graft versus host disease (GVHD) which is reported in one out of 22 cases $(5 \%)$, and passenger lymphocyte syndrome, which was not observed.

Outcome analysis of 53 kidney recipients following HCT reveals an actuarial patient survival of 85 percent, death censored graft survival of 81 percent at a mean follow-up of around four years. Recipient mean age of 18.4 years (range 3-64) at time of SOT is significantly lower compared to non-HCT kidney recipients. The twelve percent rejection incidence is lower compared to non-HCT renal recipients. Seven recipients died $(15 \%)$ because of infectious complications $(n=3 ; 6 \%)$, malignancies $(n=2 ; 4 \%)$ and myocardial infarction $(n=1 ; 2 \%)$, respectively. Metastatic squamous cell carcinoma of the tongue caused death at 2.2 years following kidney transplantation in one patient 7.4 years out of non-Hodgkin lymphoma at an age of 43 years. Two cardiac mortalities were reported nine years post kidney transplantation. Low rejection incidence and high rate of fatal infections and malignancies suggests that kidney transplant recipients following HCT are over immunosuppressed or reflect long term exposure to immunosuppressive agents.

\section{Liver transplantation (LTX) after HSCT}

Liver failure in HCT survivors is related to infectious hepatitis, veno-occlusive disease (VOD), GVHD, sepsis, drugs, or haemosiderosis. Similar to kidney transplantation, experience with liver transplantation for end-stage liver disease among HCT survivors is limited. 47 reported cases were identified (Table 2). However, liver transplantation is consistently reported feasible in selected end-stage liver disease HCT survivors. Early LTX, i.e., within four months after HSCT, was performed for acute liver failure due to VOD in 18 patients and acute GVHD in 5 patients. Later LTX was carried out for chronic liver-GVHD, cirrhosis secondary to viral hepatitis in two patients or liver failure for chronic mycobacterial disease, Lyell's syndrome (toxic epidermal necrolysis), congenital interferon-c receptor deficiency and post LTX intrahepatic ischemic biliary tract lesions in one patient each. Stratifying recipients receiving LTX within the first 4 months following HCT mortality was 71 percent, whereas there was no mortality observed in 


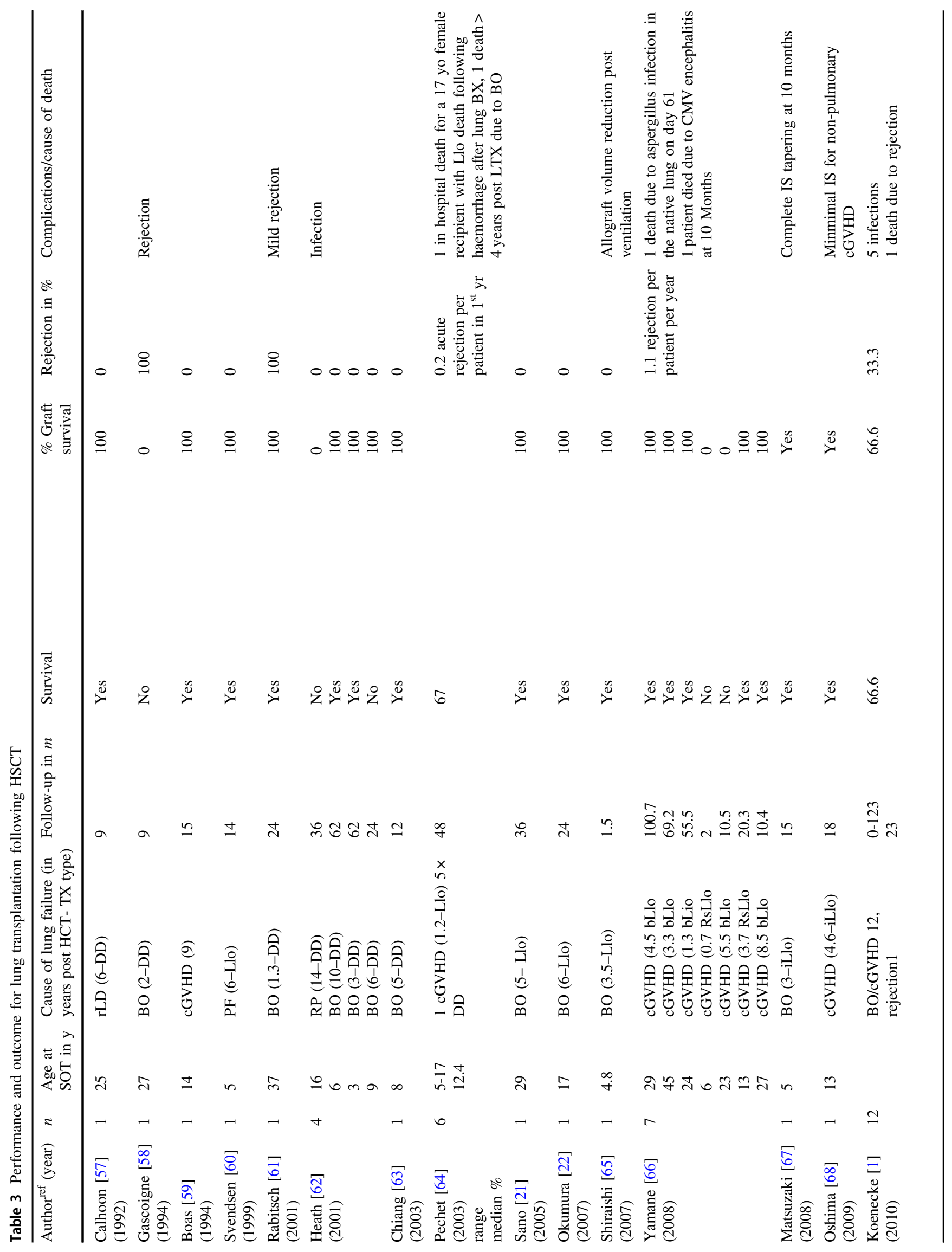




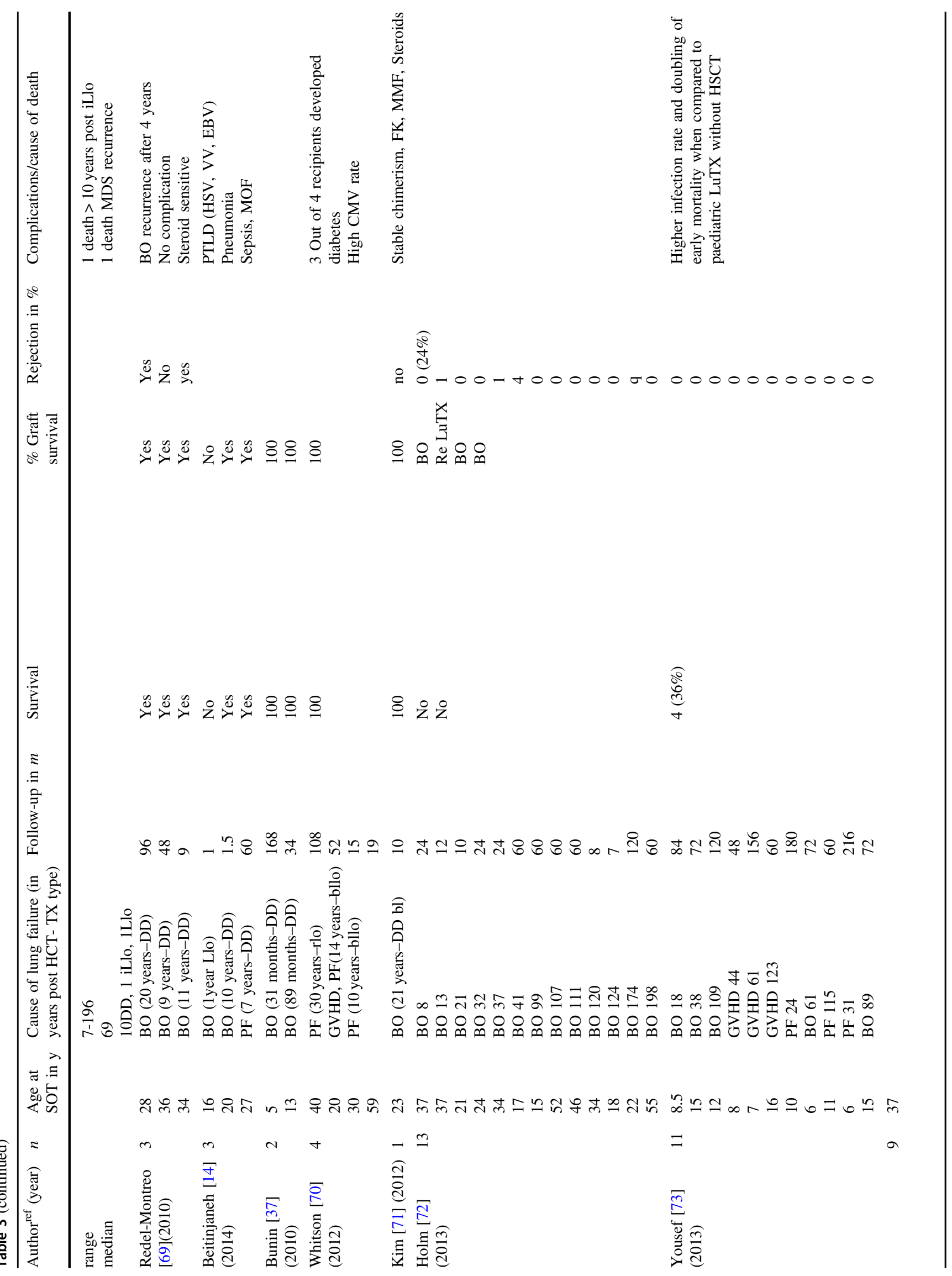




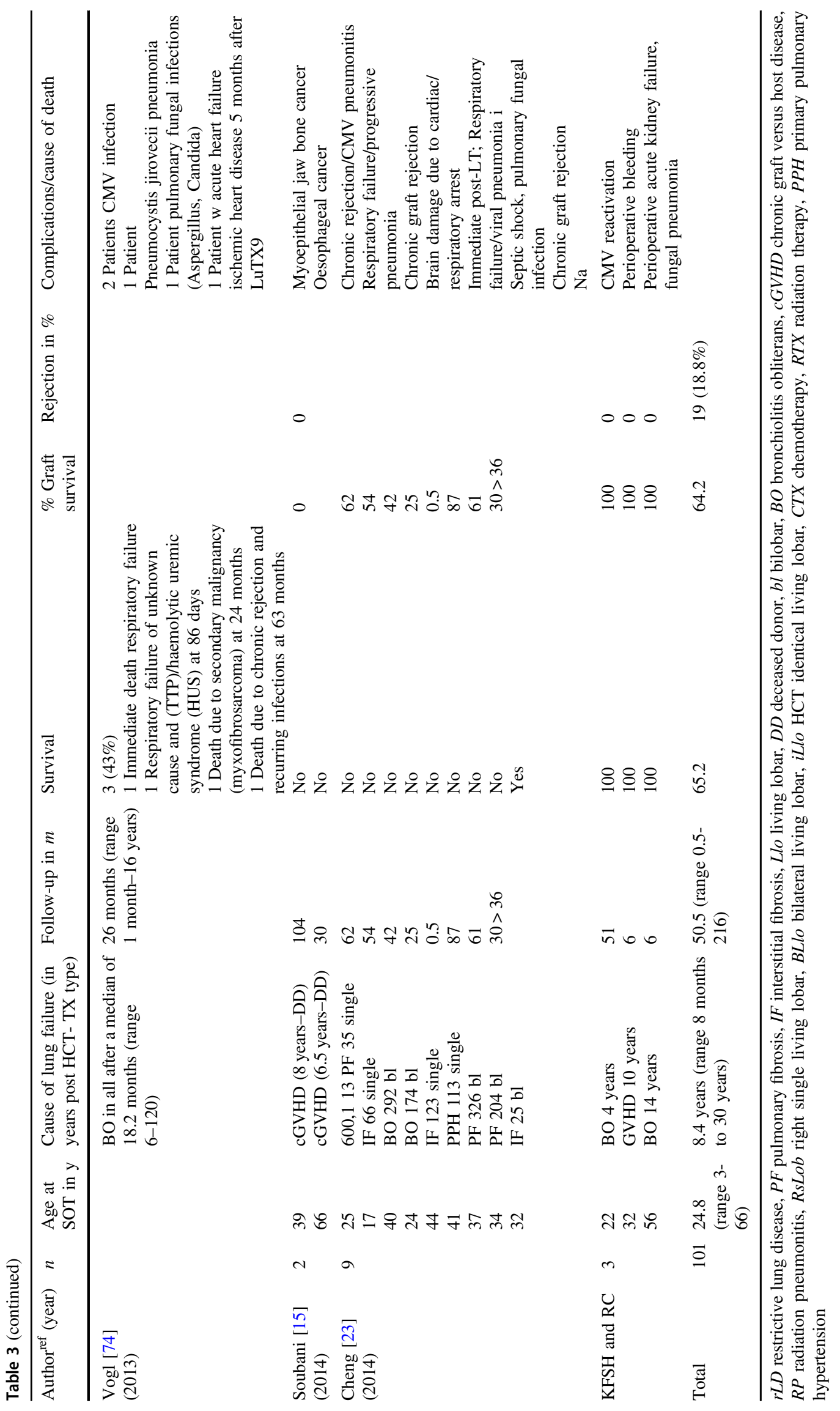


patients with a liver transplant 4 months or later following HSCT.

LTX recipient age of 24.4 years (range $0.5-55$ ) is low compared to recipients with no prior HCT. Mortality for patients undergoing deceased donor LTX was $62 \%$, whereas mortality for living donor LTX was $14 \%(n=1)$ resulting in an overall mortality of $55 \%$ at 29 months follow-up. The single mortality related to living donor LTX was for an urgent re-transplant following deceased donor LTX.

Average time to death following LTX was 3.2 months (range 0.3-8). Infection was most frequent cause for death ( $n=9,43 \%)$, namely multi organ failure $(n=4,20 \%)$, aspergillosis $(n=2,10 \%)$, pneumonia $(n=2,10 \%)$ and one ARDS. Other causes were thrombocytopenic purpura ( $n=2,10 \%)$, and single incidences of VOD recurrence, graft failure, kidney failure, hepatic and superior mesentery artery thrombosis, pancytopenia, cerebral oedema, rejection and GVHD.

Three out of 25 patients alive following LTX (11\%), were weaned off immunosuppression at one and six years. Rejection rate for LTX recipients is $13 \%$. Death censored graft survival is $96 \%$, re-transplantation rate is $4 \%$ with a mortality of $50 \%$.

\section{Lung transplantation (LuTX) following HSCT}

Main complication of HCT involving the lung is Bronchiolitis obliterans (BO) with an incidence of 1.7-32\% [1, 1419]. Other non-infectious complications include interstitial pneumonitis, pulmonary fibrosis and organising pneumonia. The pathogenesis of $\mathrm{BO}$ following allogeneic HCT remains poorly understood clinically diagnosed via pulmonary function and radiologic testing in absence of respiratory tract infection [16, 20]. Bone Marrow Transplant Registry data suggest peripheral blood stem cell source, long duration to transplant, female donor to male recipient, history of interstitial pneumonitis in addition to acute GVHD, and busulfan-based conditioning regimen as risk factors [1, 16]. There is no standard treatment for BO. In general, management consists of immunosuppression (high dose corticosteroids, calcineurin inhibitors). Response rates are limited to improvement of lung function tests in about $20 \%$ of patients [21, 22]. Results of salvage immunosuppressive therapies like calcineurin inhibitors, mycophenolate mofetil (MMF), or sirolimus are disappointing, and no randomised clinical trials have investigated their efficacy. Patients not responding to conventional treatment reveal 2-year and 5year survival rates of 20 and $13 \%$, respectively [15]. Recently, other approaches such as imatinib mesylate, antithymocyte globulins, anti-tumour necrosis factor- $\alpha$ and extracorporeal photopheresis (ECP) have been tried with variable successes [15-18]. ECP has shown to be beneficial in patients with lung involvement by chronic GVHD. Other immunosuppressive strategies, like administration of tumour necrosis factor (TNF)-alpha blockers, rituximab or imatinib, have been used in small patient numbers and to be considered experimental. In severe therapy-refractory $\mathrm{BO}$, LuTX can be a therapeutic option. In general, the donor of LuTX is different from hematopoietic stem cell donor. Therefore, there is high risk of rejection and relapse of $\mathrm{BO}$. Recently, there was one report of a living-donor lobar LuTX from the same donor of bone marrow [23].

It has been reported that allogeneic HCT increases risk of rejection after LuTX because of the amount of immunocompetent leucocytes present in the donor lung. However, most LuTX recipients might not experience graft rejection because long term pre-transplant immunosuppression potentially inducing a down-regulation of alloreactivity [5, 13, 24].

In 101 lung transplants (Table 3) following HCT average recipient age is 24.8 years (range 3-66). Mean time from HCT to lung transplantation was 8.4 years (range: $0.7-30$ years). At follow-up of 50.5 months patient survival is 65.2 percent. One recipient required lung re-transplantation translating to a graft survival of 61.2 percent. Mortality is due to infectious complications in seven patients $(7 \%$ aspergillosis $2 \times, \mathrm{CMV}$ encephalitis, PJP pneumonitis, 2 unspecified) and because of rejection in six cases $(6 \%)$. Recurrence of BO and relapse of disease were fatal in two patients. Post-transplant lymphoproliferative disorders (PTLD), myxofibrosarcoma and cardiac arrest were singular causes for death. Rejections were observed in $19 \%$ percent. In one patient immunosuppression was completely tapered ten months post SOT, while in another patient it was reduced for ongoing GVHD.

\section{Heart transplant (HTX) following HCT}

Severe cardiac toxicity after HCT occurs in $5-10 \%$ of patients receiving cyclophosphamide, proteasome inhibitors, particularly bortezomib, or radiation containing conditioning regimens and is characterised by loss of electrocardiographic voltage, progressive cardiac failure, or pericarditis with or without tamponade occurring within several weeks of cyclophosphamide administration [25]. On post-mortem examination, patients with fatal cardiac toxicity have haemorrhagic myocardial necrosis [26]. Although fatal haemorrhagic myocardial necrosis has been well described in patients receiving $>240 \mathrm{mg} / \mathrm{kg}$ or more cyclophosphamide, cardiac toxicity can occur after doses $<200$ $\mathrm{mg} / \mathrm{kg}$. Anthracyclines used for remission induction and consolidation therapy of acute leukaemias are known to cause dose-dependent cardiomyopathy [27] progressing to congestive heart failure.

The four HTX recipients post HCT (Table 4) all had preterminal heart failure, as a consequence of preceding 
Table 4 Heart TX following HSCT

\begin{tabular}{lllllllll}
\hline Author $^{\text {ref }}$ (year) & $n$ & $\begin{array}{l}\text { Age at } \\
\text { SOT in y }\end{array}$ & $\begin{array}{l}\text { Cause of heart failure (in months } \\
\text { post HCT- TX type) }\end{array}$ & $\begin{array}{l}\text { Follow- } \\
\text { up in m }\end{array}$ & $\begin{array}{l}\text { Survival \% Graft } \\
\text { survival }\end{array}$ & $\begin{array}{l}\text { Rejection } \\
\text { in } \%\end{array}$ & $\begin{array}{l}\text { Complications/ } \\
\text { cause of death }\end{array}$ \\
\hline Dey [75] (1998) & 2 & na & HF DCM (12) & $\begin{array}{l}12 \\
6\end{array}$ & $\begin{array}{l}\text { Yes } \\
\text { Yes }\end{array}$ & 100 & 0 & \\
Koenecke [1] (2010) & 1 & 15 & HF (138) & 12 & Yes & 100 & 0 & $\begin{array}{l}\text { Subsequent kidney } \\
\text { transplant } \\
\text { KFSH and RC }\end{array}$ \\
Toatl & 1 & 17 & HF DCM & 105 & no & 0 & 100 & $\begin{array}{l}\text { Non-adherence, } \\
\text { heavy smoking }\end{array}$ \\
\hline
\end{tabular}

$H F$ heart failure, DCM dilative cardiomyopathyl

treatments. One recipient developed ESRD due to immunosuppressive therapy and received subsequent kidney transplantation [28]. Follow-up did not exceed more than 12 months. The recipients were reported to have excellent performance status at 12 months post SOT of the heart.

\section{Discussion}

SOT following HCT is a rare event but its prevalence is increasing. While only 21 cases were reported by 1998 [26], today the number has increased by 10 -fold. Considering that more than 100,000 allogeneic HCTs were performed within the last 30 years and currently 30,000 allogenic HCT 's are being performed anually, isolated solid organ failure within this treatment regimen occurs in up to $8 \% .^{(29-32)}$ The number of reported SOT appears relatively low in only 0.02 $\%$ of HCT recipients suggesting that SOT represents a highly selected treatment modality.

Results might be influenced as physicians are more likely to publish only favourable outcomes. Notably, SOT following HCT recipients show higher incidence of benign underlying diseases. $30 \%$ of SOT patients received allogeneic HCT for non-malignant disease compared to less than $5 \%$ of patients in the EBMT registry [1] selection bias. In patients with history of malignant disease live-long immunosuppression post SOT could increase the risk of relapse. Seven percent of patients with malignant diseases as indication for HCT showed relapse after SOT, this is a fear most likely being overestimated. However, majority of SOTs have been performed late after HCT, when hazard of relapse is low compared to relapse rates within the first two years following HSCT. Two patients had a relapse of the underlying malignant disease after SOT at 10 and 85 months after SOT with a fatal outcome for both.

Despite potential publication bias, actual transplant mortality rates are higher compared to non HCT SOT recipients. Average recipient age of 23.2 years is well below overall and median age of patients who usually receive SOT [29].
Reported survival rates at 5 years post-transplantation for the general population is $91 \%, 71 \%$ and $49 \%$ for KTX, LTX and LuTX recipients, respectively [30-32]. At median follow-up of 44 months overall survival after SOT after HCT was $66.2 \%$. Stratified for the different types of SOT overall survival is $85 \%$ for kidney, $55 \%$ for liver (2 year follow-up) and 65 for lung recipients (3 year follow-up), respectively (Table 5). Three out of four patients following HTX, as well as the SPK recipient were alive at 16 months. 2-year-incidence of graft failure in kidney, liver and lung recipients is $20 \%$. Including re-transplantations the actual 2year incidence of overall SOT failure in survivors is $26 \%$. Fatal complications after SOT that led to patients' death were graft failure, lethal infections and malignancies.

A United Network for Organ Sharing (UNOS) database review of all LTX between 1998 and 2012 identified early liver failure to be more frequent than late liver failure in recipients of allogeneic HCT [33]. Outcome of LTX $<4$ months post HCT is associated with high mortality. Whether this is due to the fact that most of transplants were performed with a less than ideal graft or that the recipients had active GVHD at time of LTX remains unclear. Whether or not inevitable mortality of acute severe VOD justifies a $60 \%$ mortality of deceased donor LTX is ethically questionable. In an UNOS LTX analysis for GVHD 48 out of 112 were performed following HCT. Median survival for HCT-GVHD patients was 8.5 years. 1,3 and 5 year survival of the HCT-GVHD patients were 0.69, 0.64 and 0.59, respectively [33]. Outcome of living related LTX in the acute setting is more successful and therefore early LTX following HCT should be reserved for centres performing living related LTX only.

HLA compatibility could play a pivotal role in obtaining better results in living related donor compared to deceased donor graft origin in LTX following HCT, as a higher estimated degree of HLA matching within the setting of living related LTX is likely.

Twenty-two kidney, three liver and one lung transplant recipient received grafts from related donors. In 28 patients 
Table 5 Overall outcome for SOT per Organ for SOT following HSCT

\begin{tabular}{llllllllll}
\hline Organ & $N$ & $\begin{array}{l}\text { Age } \\
\text { at } \\
\text { SOT }\end{array}$ & $\begin{array}{l}\text { FU } \\
\text { in m }\end{array}$ & $\begin{array}{l}\text { Pat } \\
\text { survival } \%\end{array}$ & $\begin{array}{l}\text { Graft } \\
\text { survival } \%\end{array}$ & $\begin{array}{l}\text { Rejection } \\
\text { rate } \%\end{array}$ & $\begin{array}{l}\text { Infection } \\
\text { rate } \%\end{array}$ & $\begin{array}{l}\text { Malignancy } \\
\text { rate \% (letal) }\end{array}$ & $\begin{array}{l}\text { Freedom of } \\
\text { IS n }=(\%)\end{array}$ \\
\hline Lung & 101 & 25 & 51 & 65.2 & 64 & 19 & 27 & 3 & n.a. \\
Kidney & 53 & 18 & 47 & 85 & 81 & 14 & 13 & 3 & $6(11)$ \\
Liver & 47 & 25 & 28 & 55 & 53 & 17 & 15 & 0 & $3(6)$ \\
Heart & 4 & 16 & 34 & 75 & 75 & 25 & 0 & 0 & n.a \\
Pancreas & 1 & 34 & 24 & 100 & 100 & 0 & 100 & 0 & n.a. \\
Total & 206 & 23.1 & 45 & 63.1 & 63.3 & 17.3 & 20.5 & 2.9 & 9 (4) \\
\hline
\end{tabular}

receiving SOT, the organ donor was the same as the HCT donor. This was probably done cherishing hope that the recipient tolerates the SOT without additional immunosuppressive therapy [34]. Notably, six of 22 kidney recipients and three out of six liver recipients were weaned off immunosuppression after SOT completely. One KTX and one LuTX recipient were only on single-drug immunosuppressive therapy. Although of particular interest the reviewed reports did not mention incidence, degree and duration of macrochimerism most likely being causative effect for this phenomenon $[35,36]$.

Of concern is the high incidence of malignancy following SOT post HCT. Four percent of all analysed recipients developed lethal malignancies; PTLD in 2 and tongue cancer, oesophageal SCC, vaginal SCC, and myoepithelial jaw bone cancer in one patient each. The relatively short follow up period between SOT and onset of these malignancies, suggests that recipients were likely to be overimmunosuppressed. Many previously published articles suggested that SOT can be done safely in a selected group of patients. The selection criteria are neither mentioned nor reported within the current literature. The outcome data were assumed to be in keeping of the outcomes of non-HCT SOT recipients. Considering the young recipient average age of 23.2 years and the short overall follow-up of 44 months morbidity and mortality has to be considered higher than in SOT recipients without previous HCT.

The authors recommend for SOT recipients after HCT:

- underlying haematological disorder should effectively be treated by HCT providing reasonable prognosis. If feasible, SOT should be carried out not before 2 years after HCT.

- SOT within the first 2 years of HCT should be performed in the setting of living donation.

- In case of living donor SOT utilisation of the previous HCT donor is desireable.

- In case of successful SOT after HCT, minimising immunosuppression maintenance should be attempted if possible.
Impact of induction therapy at time of SOT could not be answered by this review. Therefore, no clear recommendations can be made. Treating physicians are encouraged to follow their standard protocols. Given the relatively high rate of infectious complications depleting antibody induction should be avoided or minimised and steroid withdrawal once feasible is recommended.

\section{Conclusion}

SOT after allogeneic HCT for terminal organ failure remains a very rare event. It may offer a valuable treatment strategy in selected HCT recipients, although associated with higher morbidity and mortality.

Of particular concern is the outcome of deceased donor LTX performed within four months following HCT. Therefore, in such settings living donor LTX is recommended providing better outcome and deceased donor graft utility. Rejection rates for all types of SOT seem to be comparable. Higher incidences of infections and malignancies in SOT after HCT makes overimmunosuppression the most likely explanation. Evaluation of recipient immunologic status might help directing post-transplant immunosuppression. Selection criteria remain individual.

\section{Compliance with ethical standards}

Conflict of interest The authors declare that they have no conflict of interest.

\section{References}

1. Koenecke C, Hertenstein B, Schetelig J, van Biezen A, Dammann E, Gratwohl A, et al. Solid organ transplantation after allogeneic hematopoietic stem cell transplantation: a retrospective, multicenter study of the EBMT. Am J Transplant. 2010;10: 1897-906.

2. Hingorani S, Guthrie KA, Schoch G, Weiss NS, McDonald GB. Chronic kidney disease in long-term survivors of hematopoietic cell transplant. Bone Marrow Transplant. 2007;39:223-9. 
3. Al-Hazzouri A, Cao Q, Burns LJ, Weisdorf DJ, Majhail NS. Similar risks for chronic kidney disease in long-term survivors of myeloablative and reduced-intensity allogeneic hematopoietic cell transplantation. Biol Blood Marrow Transplant. 2008;14:658-63.

4. Hingorani S. Chronic kidney disease in long-term survivors of hematopoietic cell transplantation: epidemiology, pathogenesis, and treatment. J Am Soc Nephrol. 2006;17:1995-2005.

5. Ellis MJ, Parikh CR, Inrig JK, Kanbay M, Patel UD. Chronic kidney disease after hematopoietic cell transplantation: a systematic review. Am J Transplant. 2008;8:2378-90.

6. Scales DC, Thiruchelvam D, Kiss A, Sibbald WJ, Redelmeier DA. Intensive care outcomes in bone marrow transplant recipients: a population-based cohort analysis. Crit Care. 2008;12:R77.

7. Sayegh MH, Fine NA, Smith JL, Rennke HG, Milford EL, Tilney $\mathrm{NL}$, et al. Immunologic tolerance to renal allografts after bone marrow transplants from the same donors. Ann Intern Med. 1991;114:954-5.

8. Jacobsen N, Taaning E, Ladefoged J, Kristensen JK, Pedersen FK. Tolerance to an HLA-B, DR disparate kidney allograft after bonemarrow transplantation from same donor. Lancet. 1994;343:800.

9. Helg C, Chapuis B, Bolle JF, Morel P, Salomon D, Roux E, et al. Renal transplantation without immunosuppression in a host with tolerance induced by allogeneic bone marrow transplantation. Transplantation. 1994;58:1420-2.

10. Sorof JM, Koerper MA, Portale AA, Potter D, DeSantes K, Cowan $\mathrm{M}$, et al. Renal transplantation without chronic immunosuppression after T cell-depleted, HLA-mismatched bone marrow transplantation. Transplantation. 1995;59:1633-5.

11. Butcher JA, Hariharan S, Adams MB, Johnson CP, Roza AM, Cohen EP, et al. Renal transplantation for endstage renal disease following bone marrow transplantation: a report of six cases, with and without immunosuppression. Clin Transplant. 1999;13:330-5.

12. Hamawi K, De Magalhaes-Silverman M, Bertolatus JA. Outcomes of renal transplantation following bone marrow transplantation. Am J Transplant. 2003;3:301-5.

13. Thomas SE, Hutchinson RJ, DebRoy M, Magee JC. Successful renal transplantation following prior bone marrow transplantation in pediatric patients. Pediatr Transplant. 2004;8:507-12.

14. Beitinjaneh A, Burns LJ, Majhail NS. Solid organ transplantation in survivors of hematopoietic cell transplantation: a single institution case series and literature review. Clin Transplant. 2010;24: E94-102.

15. Soubani AO, Kingah P, Alshabani K, Muma G, Haq A. Lung transplantation following hematopoetic stem cell transplantation: report of two cases and systematic review of literature. Clin Transplant. 2014;28:776-82.

16. Orens JB, Estenne M, Arcasoy S, Conte JV, Corris P, Egan JJ, et al. Pulmonary Scientific Council of the International Society for Heart and Lung Transplantation. J Heart Lung Transplant. 2006;25:745-55.

17. van den Brink MR, Porter DL, Giralt S, Lu SX, Jenq RR, Hanash A, et al. Relapse after allogeneic hematopoietic cell therapy. Biol Blood Marrow Transplant. 2010;16:S138.

18. Christie JD, Edwatds LB, Kucheryavaya AY, Benden C, Dipchand AI, Dobbels F, et al. The Registry of the International Society for Heart and Lung Transplantation: 29th adult lung and heart-lung transplant report-2012. J Heart Lung Transplant. 2012;31:1073-86.

19. Ramrakha PS, Marks DI, O’Brien SG, Yacoub M, Schofield JB, Goldman JM, et al. Orthotopic cardiac transplantation for dilated cardiomyopathy after allogeneic bone marrow transplantation. Clin Transplant. 1994;8:23-6.

20. Jagasia MH, Greinix HT, Arora M, Williams KM, Wolff D, Cowen EW, et al. National Institutes of Health Consensus Development Project on Criteria for Clinical Trials in Chronic
Graft-versus-Host Disease: I. The 2014 Diagnosis and Staging Working Group report. Biol Blood Marrow Transplant. 2015;21:389-401.

21. Sano Y, Date H, Nagahiro I, Aoe M, Shimizu N. Living-donor lobar lung transplantation for bronchiolitis obliterans after bone marrow transplantation. Ann Thorac Surg. 2005;79:1051-2.

22. Okumura H, Ohtake S, Ontachi Y, Ozaki J, Shimadoi S, Waseda Y, et al. Living-donor lobar lung transplantation for bronchobronchiolitis obliterans after allogeneic hematopoietic stem cell transplantation: does bronchiolitis obliterans recur in transplanted lungs? Int J Hematol. 2007;86:369-73.

23. Cheng GS, Edelman JD, Madtes DK, Martin PJ, Flowers ME. Outcomes of lung transplantation after allogeneic hematopoietic stem cell transplantation. Biol Blood Marrow Transplant. 2014;20:1169-75.

24. Younge J, Duffner UA, Bunchman T, Abdel-Mageed A. Ten year follow-up for a patient postmatched unrelated donor bone marrow transplant followed by same donor kidney transplant: normal renal function without immunosuppression. Transplantation. 2015;99: e162.

25. Goldberg MA, Antin JH, Guinan EC, Rappeport JM. Cyclophospharnide cardiotoxicity: an analysis of dosing as a risk factor. Blood. 1986;68:1114-8.

26. Gottdiener JS, Appelbaum FR, Ferrans VJ, Deisseroth A, Ziegler J. Cardiotoxicity associated with high-dose cyclophospharnide therapy. Arch Intern Med. 1981;141:758-63.

27. Lipshultz SE, Colan SD, Gelber RD, Perez-Atayde AR, Sallan SE, Sanders SP. Late cardiac effects of doxorubicin therapy for acute lymphoblastic leukemia in childhood. $\mathrm{N}$ Engl $\mathrm{J}$ Med. 1991;324:808-15.

28. Kanj SS, Sharara AI, Shpall EJ, Jones RB, Peters WP. Myocardial ischemia associated with high-dose carrnustine infusion. Cancer. 1991;68:1910-2.

29. Andreoni KA, Lin JI, Groben PA. Liver transplantation 27 years after bone marrow transplantation from the same living donor. $\mathrm{N}$ Engl J Med. 2004;350:2624-5.

30. Bunin N, Leahey A, Dunn S. Related donor liver transplant for veno-occlusive disease following T-depleted unrelated donor bone marrow transplantation. Transplantation. 1996;61:664-6.

31. Figuera A, Tomas JF, Otero MJ, Moreno E, Garcia I, FernandezRanada JM, et al. Orthotopic liver transplantation for acute grade IV hepatic graft-versus-host disease following bone marrow transplantation. Am J Hematol. 1996;52:68-9.

32. Hägglund $\mathrm{H}$, Ringden $\mathrm{O}$, Ericzon $\mathrm{BG}$, Ljungman $\mathrm{P}$, Lönnqvist $\mathrm{B}$, Winiarski J, et al. Treatment of hepatic venoocclusive disease with recombinant human tissue plasminogen activator or orthotopic liver transplantation after allogeneic bone marrow transplantation. Transplantation. 1996;62:1076-80.

33. Hashmi S, Taner T, Patnaik M, Leise M, Hathcock M, Kremers WK, et al. Liver transplantation for hepatic graft-versus-hostdisease: A United Network for Organ Sharing (UNOS) Database Study. Biol Blood Marrow Transplant. 2015;21:S331.

34. Shimizu T, Kasahara M, Tanaka K. Living-donor liver transplantation for chronic hepatic graft-versus-host disease. $\mathrm{N}$ Engl $\mathrm{J}$ Med. 2006;354:1536-7.

35. Zuber J, Rosen S, Shonts B, Sprangers B, Savage TM, Richman S, et al. Macrochimerism in intestinal transplantation: association with lower rejection rates and multivisceral transplants, without GVHD. Am J Transplant. 2015;15:2691-703.

36. Scandling JD, Busque S, Lowsky R, Shizuru J, Shori A, Engleman E, et al. Macrochimerism and clinical transplant tolerance. Hum Immunol. 2018;79:266-71.

37. Bunin N, Guzikowski V, Rand ER, Goldfarb S, Baluarte J, Meyers K, et al. Solid organ transplants following hematopoietic stem cell transplant in children. Pediatr Transplant. 2010;14:1030-5. 
38. Fangmann J, Kathrin Al-Ali H, Sack U, Kamprad M, Tautenhahn HM, Faber S, et al. Kidney transplant from the same donor without maintenance immunosuppression after previous hematopoietic stem cell transplant. Am J Transplant. 2011;11:156-62.

39. Schwarz C, Lawitschka A, Böhmig GA, Dauber EM, Greinix H, Kozakowski N, et al. Kidney transplantation with corticosteroids alone after haploidentical HCT from the same donor. Transplantation. 2016;100:2219-21.

40. Rapoport AP, Doyle HR, Starzl T, Rowe JM, Doeblin T, DiPersio $\mathrm{JF}$, et al. Orthotopic liver transplantation for life-threatening venoocclusive disease of the liver after allogeneic bone marrow transplant. Bone Marrow Transplant. 1991;8:421-4.

41. Nimer SD, Milewicz AL, Champlin RE, Busuttil RW. Successful treatment of hepatic venoocclusive disease in a bone marrow transplant patient with orthotopic liver transplantation. Transplantation. 1990;49:819-21.

42. Rhodes DF, Lee WM, Wingard JR, Pavy MD, Santos GW, Shaw $\mathrm{BW}$, et al. Orthotopic liver transplantation for graft-versus-host disease following bone marrow transplantation. Gastroenterology. 1990;99:536-8.

43. Marks DI, Dousset B, Robson A, Imviros G, Buckels JA, Elias E, et al. Orthotopic liver transplantation for hepatic GVHD following allogeneic BMT for chronic myeloid leukaemia. Bone Marrow Transplant. 1992;10:463-6.

44. Schlitt HJ, Tischler HJ, Ringe B, Radatz G, Maschek H, Dietrich $\mathrm{H}$, et al. Allogeneic liver transplantation for hepatic venoocclusive disease after bone marrow transplantation-clinical and immunological considerations. Bone Marrow Transplant. 1995;16:473-8.

45. Dowlati A, Honore P, Damas P, Deprez M, Delwaide J, Fillet G, et al. Hepatic rejection after orthotopc liver transplantation for hepatic veno-occlusive disease or graft-versus-host disease following bone marrow transplantation. Transplantation. 1995;60:106-9.

46. Rosen HR, Martin P, Schiller GJ, Territo M, Lewin DN, Shackelton CR, et al. Orthotopic liver transplantation for bone-marrow transplant-associated veno-occlusive disease and graft-versus-host disease of the liver. Liver Transpl Surg. 1996;2:225-32.

47. Norris S, Crosbie O, McEntee G, Traynor O, Nolan N, McCann S, et al. Orthotopic liver transplantation for veno-occlusive disease complicating autologous bone marrow transplantation. Transplantation. 1997;63:1521-4.

48. Salat C, Holler E, Wolf C, Kolb HJ, Reinhardt B, Pihusch R, et al. Laboratory markers of veno-occlusive disease in the course of bone marrow and subsequent liver transplantation. Bone Marrow Transplant. 1997;19:487-90.

49. Urban CH, Deutschmann A, Kerbl R, Lackner H, Schwinger W, Königsrainer A, et al. Organ tolerance following cadaveric liver transplantation for chronic graft-versus-host disease after allogeneic bone marrow transplantation. Bone Marrow Transplant. 2002;30:535-7.

50. Kim ID, Egawa H, Marui Y, Kaihara S, Haga H, Lin YW, et al. A successful liver transplantation for refractory hepatic venoocclusive disease originating from cord blood transplantation. Am J Transplant. 2002;2:796-800.

51. MacQuillan GC, Mutimer D. Fulminant liver failure due to severe veno-occlusive disease after haematopoietic cell transplantation: a depressing experience. QJM. 2004;97:581-9.

52. Orlando G, Ferrant A, Schots R, Goffette P, Mathijs J, Lemaire J, et al. Liver transplantation for chronic graft-versus-host disease: case report with 10-year follow-up. Transpl Int. 2005;18:125-9.

53. Barshes NR, Myers GD, Lee D, Karpen SJ, Lee TC, Patel AJ, et al. Liver transplantation for severe hepatic graft-versus-host disease: an analysis of aggregate survival data. Liver Transpl. 2005;11:525-31.
54. Koenecke C, Kleine M, Schrem H, Krug U, Nashan B, Neipp M, et al. Sinusoidal obstruction syndrome of the liver after hematopoietic stem cell transplantation: decision making for orthotopic liver transplantation. Int J Hematol. 2006;83:271-4.

55. Membreno FE, Ortiz J, Foster PF, Wright F, Ostrower VS, Metter $\mathrm{JD}$, et al. Liver transplantation for sinusoidal obstructive syndrome (veno-occlusive disease): case report with review of the literature and the UNOS database. Clin Transplant. 2008;22:397-404.

56. Mahansaria SS, Kumar S, Bharathy KG, Kumar S, Pamecha V. Liver transplantation after bone marrow transplantation for end stage liver disease with severe hepatopulmonary syndrome in dyskeratosis congenita: a literature first. J Clin Exp Hepatol. 2015;5:344-7.

57. Calhoon JH, Levine S, Anzueto A, Bryan CL, Trinkle JK. Lung transplantation in a patient with a prior bone marrow transplant. Chest. 1992;102:948.

58. Gascoigne A, Corris P. Lung transplants in patients with prior bone marrow transplants. Chest. 1994;105:327.

59. Boas SR, Noyes BE, Kurland G, Armitage J, Orenstein D. Pediatric lung transplantation for graft-versus-host disease following bone marrow transplantation. Chest. 1994;105:1584-6.

60. Svendsen UG, Aggestrup S, Heilmann C, Jacobsen N, Koch C, Larsen B, et al. Transplantation of a lobe of lung from mother to child following previous transplantation with maternal bone marrow. J Heart Lung Transplant. 1999;18:388-90.

61. Rabitsch W, Deviatko E, Keil F, Herold C, Dekan G, Greinix HAT, et al. Successful lung transplantation for bronchiolitis obliterans after allogeneic marrow transplantation. Transplantation. 2001;71:1341-3.

62. Heath JA, Kurland G, Spray TL, Kernan NA, Small TN, Brochstein JA, et al. Lung transplantation after allogeneic marrow transplantation in pediatric patients: the Memorial Sloan-Kettering experience. Transplantation. 2001;72:1986-90.

63. Chiang KY, Lazarus HM. Should we be performing more combined hematopoietic stem cell plus solid organtransplants? Bone Marrow Transplant. 2003;31:633-42.

64. Pechet TV, De le Morena M, Mendeloff EN, Sweet SC, Shapiro $\mathrm{SD}$, Huddleston CB. Lung transplantation in children following treatment for malignancy. J Heart Lung Transplant. 2003;22:154-60.

65. Shiraishi T, Hiratsuka M, Munakata M, Higuchi T, Makihata S, Yoshinaga $\mathrm{Y}$, et al. Living-donor single-lobe lung transplantation for bronchiolitis obliterans in a 4-year-old boy. Thorac Cardiovasc Surg. 2007;134:1092-3.

66. Yamane M, Sano Y, Toyooka S, Okazaki M, Date H, Oto T, et al. Living-donor lobar lung transplantation for pulmonary complications after hematopoietic stem cell transplantation. Transplantation. 2008;86:1767-70.

67. Matsuzaki A, Suminoe A, Koga Y, Hara T, Shiraishi T. Lung transplantation after hematopoietic stem cell transplantation from the same living donor in a child with juvenile myelomonocytic leukemia and bronchiolitis obliterans. Pediatr Blood Cancer. 2008;51:567.

68. Oshima K, Kikuchi A, Mochizuki S, Yamane M, Date H, Hanada $\mathrm{R}$, et al. Living-donor single lobe lung transplantation for bronchiolitis obliterans from mother to child following previous allogeneic hematopoietic stem cell transplantation from the same donor. Int J Hematol. 2009;90:540-2.

69. Redel-Montero J, Bujalance-Cabrera C, Vaquero-Barrios JM, Santos-Luna F, Arenas-De Larriva M, Moreno-Casado P, et al. Lung transplantation for bronchiolitis obliterans after allogenic bone marrow transplantation. Transplant Proc. 2010;42:3023-5.

70. Whitson BA, Shelstad RC, Hertz MI, Kelly RF, D'Cunha J, Shumway SJ, et al. Lung transplantation after hematopoietic stem cell transplantation. Clin Transplant. 2012;26:254-7. 
71. Kim MYR, Haam SJ, Park YG, Lim BJ, Park YM, Paik HC. Lung transplantation for bronchiolitis obliterans after allogeneic hematopoietic stem cell transplantation. Yonsei Med J. 2012;53:1054-7.

72. Holm AM, Riise GC, Hansson L, Brinch L, Bjørtuft O, Iversen M, et al. Lung transplantation for bronchiolitis obliterans syndrome after allo-SCT. Bone Marrow Transplant. 2013;48:703-7.

73. Yousef S, Benden C, Boyer D, Elidemir O, Frischer T, Goldfarb $\mathrm{S}$, et al. Lung transplantation in children following bone marrow transplantation: a multi-center experience. Pediatr Transplant. 2013;17:231-6.

74. Vogl UM, Nagayama K, Bojic CM, Hoda MAR, Klepetko W, Jaksch $\mathrm{P}$, et al. Lung transplantation for bronchiolitis obliterans after allogeneic hematopoietic stem cell transplantation: a singlecenter experience. Transplantation. 2013;95:623-8.

75. Dey B, Skyes M, Spitzner TE. Outcomes of recipients of both bone marrow and solid organ transplants. Medicine. 1998;77:355-69. 